\title{
REVISION OF THE TWO-WINGED FLIES OF THE GENUS COELOPA MEIGEN IN NORTH AMERICA
}

\author{
By J. M. Aldprich
}

Associate Curator, Division of Insects, United States National Museum

The present revision has been prepared as the result of recent correspondence with Mr. J. E. Collin, of Newmarket, England, who has furnished information relating to synonomy and has also supplied the Museum with determined European specimens; from his data and the specimens it appears that the North American members of the genus have been misidentified to a large extent. Two species from the Bering Sea region, formerly considered to be identical with European forms, are here described as new.

All the species appear to breed in the kelps, and are found only on seashores where seaweeds of this group are washed up. This limits the distribution of the flies on the Atlantic side to the northern coast, with Rhode Island as the southern terminus, but on the Pacific the kelps extend much farther south, so that one species of the fly is common at least as far south as San Diego, Calif.

\section{Genus COELOPA Meigen}

Coelopa Meigen, Syst. Beschr., vol. 6, 1830, p. 8.-Haliday, Ann. Nat. Hist., vol. 2, 1839, p. 186.-Westwood, Introd. Mod. Classif. Ins., vol. 2, Synops., 1840, p. 144.-Stenhammar, Skandinaviens Copromyzinae (Kongl. Vetensk. Akad. Handl.) 1853 (1855), p. 317.-Loww, Mon. N. Amer. Dipt., vol. 1, 1862, p. 42.-Schiner, Fauna Austriaca, Diptera, vol. 2, 1864, p. 319.-Cole and LovetT, List Dipt. of Oregon (Proc. Cal. Acad. Sci., ser. 4, vol. 11) 1921, p. 320.-Williston, Manual N. Amer. Dipt., ed. 3d., 1908, p. 317.-Malloch, N. Amer. Fauna No. 46, 1923, p. 214, keys to species.

Fucomyia Haliday, Ann. Nat. Hist., vol. 2, 1839, p. 186.-Westwood, Introd.

Mod. Classif. Ins., vol. 2, Synops., 1840, p. 144.

The genotypes of Coelopa and Fucomyia have been remarkably confused, owing to the misidentification of Musca frigida Fabricius. This was the only species included in Coelopa by Meigen in 1830, but Haliday in 1839 recognized that it was not the true frigida of Fabricius, and gave the name pilipes to Meigen's species, which thus attains the status of genotype and has been so accepted by $\mathrm{Mr}$. Collin, although the matter has not been discussed in print. 
Fucomyia had originally three species-the first was what Haliday thought to be the true frigida of Fabricius, which he distinguished from the frigida of Meigen; of the former he makes his own gravis 1833 a synonym. The other two species included are simplex and parvula, both new. Westwood (1840, p. 144) makes frigida Fabricius the genotype of Fucomyia. But here, again, is a misidentification of frigida, which is not a Coelopa at all, but probably a Scatophaga (Stenhammar, Copyromyz., 1855, p. 269). Haliday's supposed frigida Fabricius is disposed of by adopting gravis Haliday, 1833 for it, since Haliday himself indicated the synonymy. Thus gravis Haliday becomes the genotype of Fucomyia. The question is not of prime importance, since Fucomyia is undoubtedly a synonym of Coelopa. Fucomyia has bristly legs, while in Coelopa they are pilose; but this applies only to males, and is best developed in the large males, smaller ones showing much less difference, and females showing hardly a specific difference, much less a generic one.

The genus Coelopa is the main component of the small acalyptrate family Coelopidae, which is distinguished by the following characters in Hendel's recent key to the families of Diptera. ${ }^{1}$

Body depressed, postverticals well developed, convergent or crossed; prelabrum protruding; tibiae with preapical bristle on dorsal side, but with apicals only on ventral side; scutellum with a pair of erect, crossed apical bristles, curving forward; auxiliary vein complete, costa not broken or interrupted at tip of auxiliary or before it.

In Coelopa the face in profile is very deeply hollowed; the sides of the epistoma are bulging; the anal vein reaches the margin, but only as a fold. The mesonotum is strikingly flattened, with no bristles of considerable size except a single humeral, two notopleurals and one postalar - of these the single, large erect humeral is most distinctive. The antennae are rather small, the third joint rounded, with bare arista.

No other genus of the family occurs in North America; in our literature Omomyia Coquillett has been referred here, but it appears to show more affinity to the Scatophagidae.

All of the species vary greatly in size; specimens of vanduzeci, which are all recognizable by the hairs on the apical portion of the first vein, vary from three to seven millimeters in length. In all cases the larger are more spinose or pilose, the striking vestiture being reduced with the size until it becomes inconspicuous. On this account I have given up parvula as a name for our smaller New England specimens, without attempting to decide whether there is a

1 Tierwelt Deutschlands, Jena, 1928, part 11, section 2, pp. 86-89. 
valid European species to which the name may be applied. Mr. Collin, however, says that gravis and parvula always occur together, which casts doubt upon the validity of the latter.

I have omitted Coelopa anomala Cole $^{2}$, from Lower California, which is said to have a convex thorax instead of the flattened one which is so characteristic in the genus, and probably does not belong: here. At any rate the form of the thorax will separate it.

KEY TO NORTH AMERICAN SPECIES OF COELOPA

MALES

1. First vein with a few hairs on apical part; middle tibiae pilose, the others spiny (California, Oregon) vanduzeei Cresson.

Firat vein entirely bare. $-2$.

2. All femora and tibiae with dense, long soft pile, like that of middle basitarsus, not at all bristly (Bering Sea)________stejnegeri, new species.

All femora and tibiae spiny in the larger specimens, bristly in the smaller, but in all cases the pile of the middle basitarsus is evidently much softer and more delicate than this

3. Abdomen with spiny bristles not only on sides and hind margin but scattered over the disk of the last three segments (Bering Sea region).

nebularum, new species.

Abdomen with spiny bristles only on hind margin and sparsely on sides (North Atlantic Coast) gravis Haliday.

\section{FEMALES}

1. First vein with a few hairs on apical part (California and Oregon).

vanduzeei Cresson.

First vein entirely bare

2. Legs usually blackish (North Pacific Coast)

Legs reddish yellow (North Atlantic Coast)

3. Cheek with dense, soft, rather short hair; arista minutely setulose under high power stejnegeri, new species.

Cheek with sparser hair, which is somewhat bristly above; arista not minutely setulose nebularum, new species.

\section{COELOPA GRAVIS Haliday}

Coelopa gravis HALIDAY, Entomological Magazine, vol. 1, 1833, p. 167.

Coelopa frigida Osten Sacken, Catalogue N. A. Dipt., 1878, p. 197 (not of Fabricius).-Hagen, Canad. Ent., vol. 17, 1885, p. 140.-Johnson, List Dipt. New Eng., 1925, p. 248; Proc. Bost. Soc. N. H., vol. 38, 1925, p. 95.

Coelopa eximia Stenhammar, Copromyzinae, 1855, p. 318.

Coelopa nitidula Osten Sacken, Catalogue N. A. Dipt., 1878, p. 197 (not of Stenhammer).

Coelopa parvula Johnson, List Dipt. New Eng., 1925, p. 248 (not of Haliday); Proc. Bost. Soc. N. H., vol. 38, 1925, p. 95.-Sruntevant, Biol. Bull., vol. 50, p. 33.

I have examined 22 specimens from the New England coastMassachusetts and Rhode Island. Johnson writes me, "They do not

${ }^{2}$ Proc Cal. Acad. Sci., vol. 12, 1923, p. 470. 
seem to be found south of where the kelp grows. Narragansett Pier, R. I., is my most southern locality. I have seen the kelp a quivering mass of maggots and later an enormous swarm of flies." Length 3 to $6 \mathrm{~mm}$., the smaller recorded as parvula. Seven specimens of both sexes from European seacoasts are also in the United States National Museum, determined by Collin, Bezzi, and Lundbeck, the two latter having identified it as frigida Fabricius.

Male.-Head and body black, the antennae, palpi, and proboscis reddish; a few reddish indistinct marks below wing on pleura; hind edges of last three segments and sides of last four yellowish red; abdomen flat, with a single row of bristles on each side and across the hind margin of each segment beyond the first or second (fewer in small specimens); front femora thickened and with stout spines, front tibiae spiny, but with some appressed pile on ventral side; front basitarsus with several stout, short erect spines below near base, the apex below with a thin, expanded rim or margin, wider on mesial side. Middle femora and tibiae spiny, the latter villous on flexor side and with several stout apical spines ventrally; middle basitarsus with long hair below and behind, and with about four stout spines curved downward on the front side. Hind femora and tibiae somewhat thickened, spiny, the latter with a few more delicate hairs on the flexor side; the yellow brush of cleaning hairs begins below the middle and extends the whole length of the first and second tarsal segments.

Female.-Abdominal segments less widely bordered with reddish yellow behind, but about the same on the sides. Front femora thickened, but with only a few stout bristles above.

\section{COELOPA VANDUZEei Cresson}

Coelopa vanduzeei Cresson, Ent. News, vol. 25, 1914, p. 457.-Peterson, Ill.

Biol. Mon., vol. 3, 1916, No. 2, p. 182 (numerous morphological figures).

Coelopa frigida CoLe, First Rept. Laguna Lab., 1912, p. 156 (det. by Aldrich, not of Fabricius).-CoLe and Lovetr, List Dipt. of Oregon, 1921, p. 320.

Easily recognized by Cresson's description and by the hairs on the first vein; I place the Cole and Lovett Oregon specimens here from the excellent figure, although otherwise it is not known from that State.

I have before me 119 specimens from the California coastSan Diego (Aldrich), Laguna Beach (Cole), Santa Barbara (Blaisdell, Aldrich); Pacific Grove (Aldrich), Santa Cruz (Cole). Adults appear to occur throughout the year, as Doctor Blaisdell sent a large shipment which he collected on January 2, 1929, at Santa Barbara. Professor Hine also sent five specimens of both sexes, which he collected on Kodiak Island, Alaska, in September, 1919. 
COELOPA NEBULARUM, new species

Coelopa frigida Coquillett, Dipt. Commander Ids., 1899, p. 345 (not of Fallen, not of Fabricius) ; Proc. Wash. Acad. Sci., vol. 2, 1900, p. 460.-Malloch, North American Fauna, No. 46, 1923, p. 214, pl. 12, fig. 1.

Coelopa nitidula Coquillett, Proc. Wash. Acad. Sci., vol. 2, 1900, p. 460 (nct of Stenhammar).

Coquillett reported the species from the Commander Islands and Kodiak Island, as frigida; and as I identify the specimens he also recorded a specimen from Kodiak Island as nitidula.

Male.-Differs from gravis, which is so widespread that it may well be used for comparison, principally by the character given in the key, the posterior part of the abdomen being much more bristly above and on the sides, and also less flattened.

Female.-The legs are almost invariably blackish, while in a dozen females of gravis they are uniformly reddish yellow.

Length, 3.5 to $6.2 \mathrm{~mm}$.

Described from 15 males and 29 females, mostly from the Pribilof and Commander Islands in Bering Sea. From the former grotip, 19 of both sexes, including type and allotype, are from St. Paul Island (E. A. Preble, G. D. Hanna, A. G. Whitney), in 1914-1917; while 7 are from St. George Island (Hanna), June 6 and 14, 1914. From the Commander Islands (palaearctic), a male and two fomales (Stejneger) are from Bering Island, and a female (BarrettHamilton) is from Copper Island. One of the Stejneger females is from the early collecting in the eighties. A male and a female were collected by the Harriman Expedition (Kincaid) on Kodiak Island, in 1899, and a male from the same island (Hine) in 1917. Also two males and nine females from Katmai, Alaska, collected by Prof. J. S. Hine in 1917, and lent by him for study.

Type.-Male, Cat. No. 41859, U.S.N.M.

\section{COELOPA STEJNEGERI, new species}

Coelopa frigida Coquillett, Dipt. Commander Ids., 1899, p. 345 (not of Fabricius).

Coelopa eximia Malloch, N. Amer. Fauna, No. 46, 1923, p. 213, pl. 14, fig. 25 (not of Stenhammar).

Coelopa parvula Cole, Proc. Cal. Acad. Sci., vol. 11, 1921, p. 174 (not of Haliday).

Coelopa nitidula Coquillett, Dipt. Commander Ids., 1899, p. 345 (not of Haliday).

Coquillett reported the species from the Pribilof and Commander Islands as frigida and nitidula; Cole reported it from the former as parvula; and Malloch as eximia. The Commander Islands are in the palaearctic region, being on the western side of the North Pacific.

Male.-Black and rather shining; front opaque except the ocellar triangle and an upper border to the eye, all the opaque portion with erect hair of considerable length; the frontal bristles variable, 
sometimes absent; cheeks with dense, long pile; arista with a few scattering minute setules under high power (35 diameters). Femora almost black, with long hair and no bristles; tibiae reddish to blackish, all with long pile, the middle ones with several apical spines on lower side, middle basitarsi also pilose, with several short, curved spines on front edge below; hind tibiae with long pile, below at tip with one longer and one shorter spine. The golden brush of hairs for cleaning are conspicuous on inner side of hind tibia on apical third, and on basitarsus. Abdomen shining black, with no bristles, but a good deal of black hair, especially posteriorly.

Female.-Pilose as in male, but the pile is shorter; front with some distinct frontals, but they seem variable; cheek with dense but rather short pile.

Length, 2.7 to $5.5 \mathrm{~mm}$.

Described from nine males and eight females. The type and allotype are from St. Paul Island, Bering Sea, collected August 1, 1914, by E. A. Preble, and August 16, 1915, by G. D. Hanna. Another male and a female from the same island were collected by Hanna in 1915 and 1916, a male and female by A. G. Whitney in 1914, and another male by Preble in 1914; a male and a female from Bering Island, of the Commander group in Bering Sea (palaearctic), by Barrett-Hamilton and Dr. Leonhard Stejneger respectively, in 1897; a female from Pribilof Islands by Stejneger some years earlier, not dated; two females from Nikolaki, Bering Island, in 1895; a female frome Skagway, Alaska, June 14, 1921 (Aldrich); and a male and female from Union Bay, Vancouver Island, April 26, 1916 (Hanna). Also a male and female from Katmai, Alaska, 1917, lent by Prof. James S. Hine and collected by him.

Type.-Male, Cat. No. 41860 , U.S.N.M.

Named in honor of Dr. Leonhard Stejneger, of the United States National Museum, whose interest in the life of the Bering Sea islands has been continuous for nearly half a century.

This is the nearest of all our species to the European pilipes Haliday, type of the genus, which also has all the legs with long pile and not bristles. It however has the abdomen opaque, the dorsocentral bristles quite appreciably developed, and the front with distinct lateral bristles in the male and not so much pile. The thin expansion of the front basitarsus below its apex is less noticeable in stejnegeri than in nebularum, but in pilipes it is hardly perceptible at all. The female of stejnegeri can be distinguished from that of pilipes by its more shining abdomen. In making these comparisons I am using four European specimens of pilipes received from Mr. Collin and two from Prof. T. D. A. Cockerell. 


\title{
TWO NEW SPECIES OF TREMATODES OF THE GENUS PARAMETORCHIS FROM FUR-BEARING ANIMALS
}

\author{
By Emmett W. Price
}

Of the Zoological Division, Bureau of Animal Indusiry, United States Department of Agriculture

In this paper two trematodes which appear to be new species are described. These fiukes belong to the family Opisthorchiidae Braun, 1901, and to the genus Parametorchis Skrjabin, 1913. The first of these species was forwarded to the Bureau of Animal Industry, October 13, 1927, by Dr. J. E. Shillinger, of the Bureau of Biological Survey, who collected them from the gall bladder of a silver fox from Wisconsin. For this species the name Parametorchis intermedius is proposed. The second species, comprising about a dozen specimens, was collected from the gall bladder of a mink by Dr. Ronald G. Law, of the Experimental Fur Farm, Kirkfield, Ontario, and forwarded to the Bureau of Animal Industry for identification on February 2, 1929. For this species the name Parametorchis canadensis is proposed.

The genus to which these species obviously belong was proposed by Skrjabin (1913) and is characterized as follows:

\section{Genus PARAMETORCHIS Skrjabin, 1913}

Generic diagnosis.-Flattened, moderate-sized distomes, attenuated anteriorly and rounded posteriorly. Cuticle spiny. Suckers equal in size and weakly developed; acetabulum at the border of the first and second fourth of body length. Pharynx and a smaller esophagus present. Intestinal ceca extend to posterior end of body. Testes lobed and arranged tandem in posterior half of body. Uterus rosette-shaped, in anterior half of body, surrounding the acetabulum. Vitellaria lateral of uterus, in anterior half of body, and uniting in front of uterus. Ovary lobed, cephalad of testes. Receptaculum seminis moderately large, lateral of ovary. Parasites of the gall bladder of mammals.

Type species.-Parametorchis complems (Stiles and Hassall, 1894).

No. 2809.-Proceedings U.S. National Museum, Vol. 76, Art. 12 
Specific diagnosis.-Parametorchis: Body linguiform, the anterior end attenuated and posterior end rounded, 3 to $3.5 \mathrm{~mm}$. long by $1 \mathrm{~mm}$. wide in the region of the anterior testis. Oral sucker terminal, $155 \mu$ to $262 \mu$ long by $232 \mu$ to $278 \mu$ wide, weakly muscular. Prepharynx absent; pharynx strongly muscular, $170 \mu$ to $186 \mu$ long by $140 \mu$ wide. Esophagus very short; intestinal ceca wide and sinuous, terminating $77 \mu$ to $124 \mu$ from the posterior end of body. Acetabulum weakly developed, slightly oval transversely, $150 \mu$ long by $200 \mu$ wide, and situated about $775 \mu$ to $997 \mu$ from the anterior end. Testes deeply lobed, tandem or slightly oblique, and situated in the posterior half of body. The anterior testis is from $262 \mu$ to $310 \mu$ long by $325 \mu$ to $496 \mu$ wide and the posterior from $310 \mu$ to $500 \mu$ long by $387 \mu$ to $496 \mu$ wide. Cirrus pouch absent. Seminal vesicle slender and sinuous, and usually obscured by the convolutions of the uterus. Ovary trilobed, $108 \mu$ to $140 \mu$ long by $200 \mu$ to $260 \mu$ wide, and situated a short distance in front

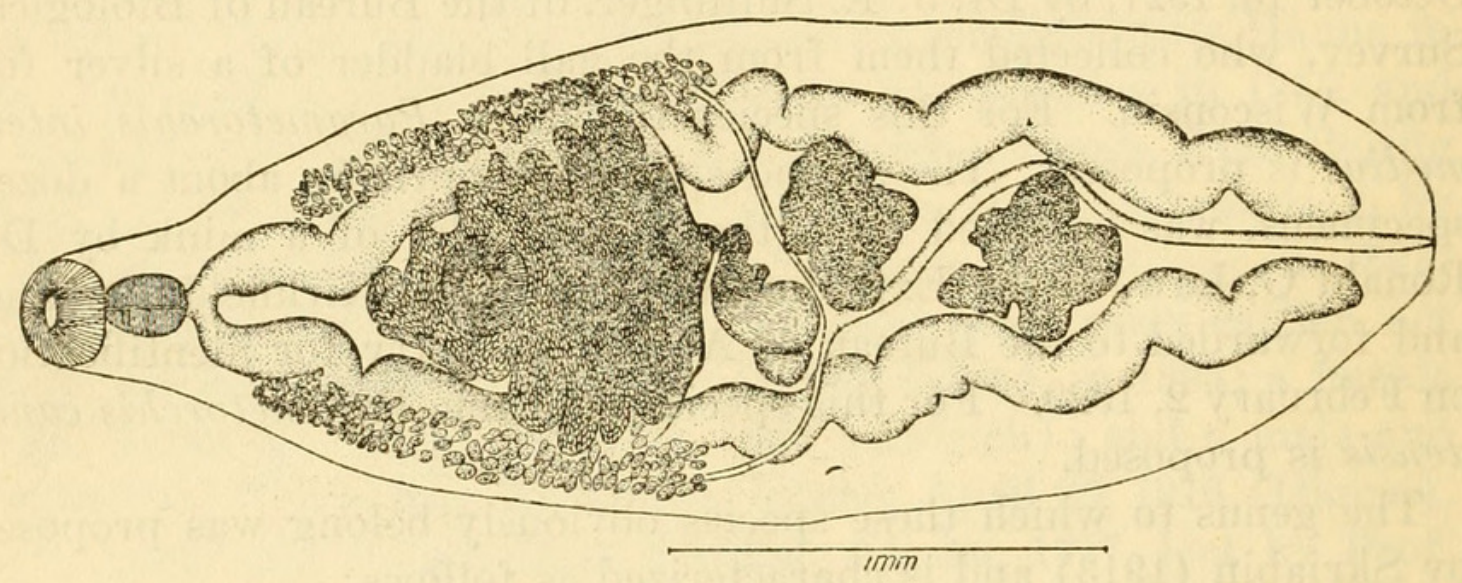

F'igure 1.-Parametorchis intermedus, new spectes. Ventral view

of the anterior testis. Receptaculum seminis elongated and slightly twisted, and situated to the right and caudad of the ovary. Vitellaria lateral, extending from slightly behind the level of the esophageal bifurcation to the level of the anterior border of the ovary. Uterus composed of close transverse coils and extending from ovary to a short distance in front of acetabulum. Genital pore median, about $850 \mu$ from the anterior end of body. Excretory canal sigmoid, branching at the level of the anterior border of the anterior testis, the two branches extending extracecally to about the level of the pharynx; excretory pore terminal. Eggs oval, $30 \mu$ long by $15 \mu$ wide, and yellowish brown in color.

Host.-Silver fox (Vulpes fulva.)

Location.-Gall bladder.

Distribution.-United States (Wisconsin.)

Type specimens.-United States National Museum Helminthological Collection No. 27857; paratypes No. 28179. 
This species apparently occupies a position intermediate between Parcmetorchis complexus, which was described by Stiles and Hassall (1894), from the gall bladder of cats from New York, Maryland, and District of Columbia, and $P$. noveboracensis which was described by Hung (1926) from the gall bladder of a cat from New York. In the former species the testes are deeply lobed and the vitellaria unite in the median line forming a $U$ around the uterus; in the latter species the testes are almost round, the posterior being only slightly indented, and the vitellaria do not unite in front of the uterus. The peculiar character of the vitellaria in $P$. complexus appears to be constant and not changed by host relationship. Specimens of this species which the writer has examined (U. S. N. M No. 14407), collected January 21, 1907, by E. C. Stevenson from a blue fox which died in the National Zoological Park, Washington, D. C., conform in this respect to the type specimens from the cat. $P$. intermedius is considerably smaller than either $P$. complexus or $P$. noveboracensis.

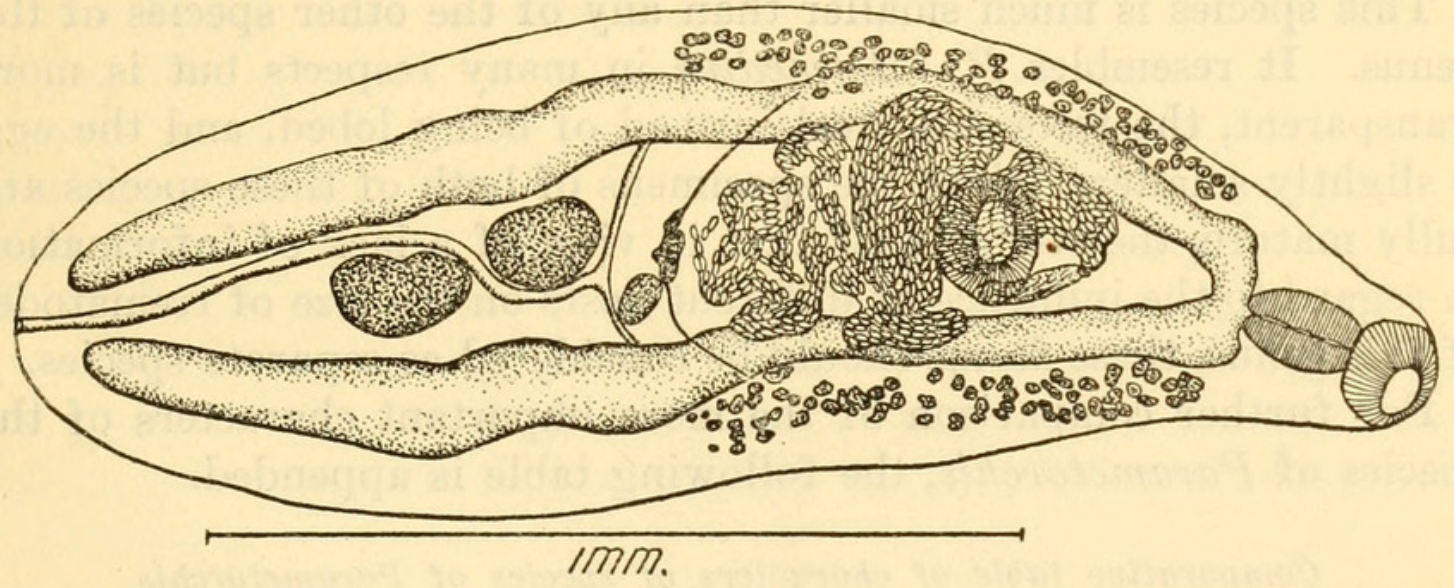

Figure 2.-Parametorchis canadensis, new species. Dorsal vlew

The body form and shape of the testes are similar to the former species, but the arrangement of the vitellaria is similar to that in the latter species. On the basis of these differences, the writer ferls justified in considering $P$. intermedius a distinct species.

PARAMETORCHIS CANADENSIS, new species

Specific diagnosis.-Parametorchis: Body linguiform, transparent, 1.7 to $2 \mathrm{~mm}$. long $590 \mu$ to $687 \mu$ wide in the region of the anterior testis. Cuticle missing owing to the somewhat macerated condition of the specimens. Oral sucker terminal, $93 \mu$ to $108 \mu$ long by $140 u$ to $155 u$ wide. Prepharynx absent; pharynx muscular, $108 \mu$ to $140 \mu$ long by $62 \mu$ to $93 \mu$ wide. Esophagus very short; intestinal ceca slightly sinuous, terminating $70 \mu$ to $90 \mu$ from the posterior end of the body. Acetabulum $125 \mu$ long by $140 \mu$ wide, weakly muscular, and situated about $470 \mu$ from the anterior end. Testes oval or slightly indented, and situated tandem in the posterior half of body; they are about equal 
in size, $186 \mu$ long by $125 \mu$ wide. Cirrus pouch absent. Seminal vesicle slender and sinuous, its posterior end lying on a level with the center of the acetabulum. Ovary trilobed, small, and situated about twice its own length in front of the bifurcation of the excretory vesicle. Receptaculum seminis large and pyriform, and situated to the right and caudad of the ovary. Vitellaria lateral, extending from a short distance caudad of the esophagus bifurcation to the level of the ovary. Uterus composed of close transverse coils which are filled with small eggs. The genital pore is situated $400 \mu$ to $600 \mu$ from the anterior end of body. Excretory system similar to that in other species of the genus. Eggs oval, $22 \mu$ long by $11 \mu$ wide, and yellowish brown in color.

Host.-Mink (Mustela vison).

Location.-Gall bladder.

Distribution.-Canada (Kirkfield, Ontario).

Type specimens.-United States National Museum Helminthological Collection No. 28180 ; paratypes No. 28366.

This species is much smaller than any of the other species of the genus. It resembles $P$. intermedius in many respects but is more transparent, the testes are oval instead of being lobed, and the egg is slightly smaller. Since the specimens of both of these species are fully mature, the writer feels that in view of a lack of information in regard to the influence of different hosts on the size of trematodes of this genus, these forms should be considered as separate species.

For further comparison of the more important characters of the species of Parametorchis, the following table is appended.

Comparative table of characters of species of Parametorchis

\begin{tabular}{|c|c|c|c|c|}
\hline & $\begin{array}{l}\text { Parametorchis } \\
\text { complexus }\end{array}$ & $\begin{array}{l}\text { Parametorchis } \\
\text { noveboracensis }\end{array}$ & $\begin{array}{c}\text { Parametorchis } \\
\text { intermedius }\end{array}$ & $\begin{array}{c}\text { Parametorchis } \\
\text { canadensis }\end{array}$ \\
\hline 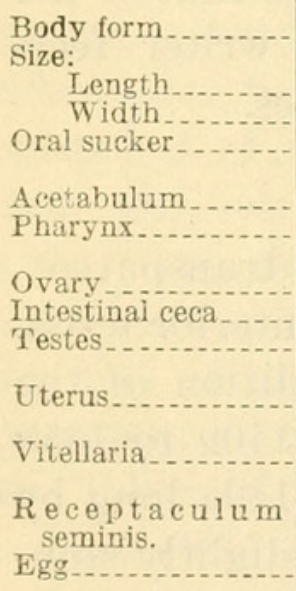 & 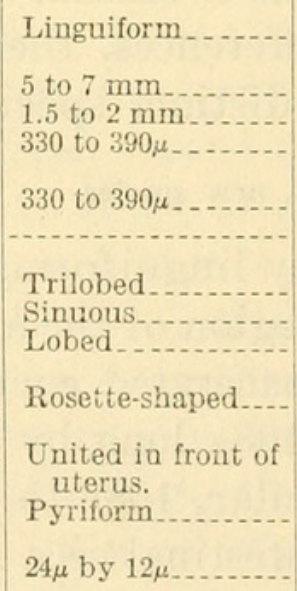 & $\begin{array}{l}\text { Linguiform } \\
6 \text { to } 6.3 \mathrm{~mm} \\
2.2 \text { to } 2.6 \mathrm{~mm} \\
232 \text { to } 242 \mu \\
232 \text { to } 242 \mu \text { by } 281 \text { to } \\
300 \mu \text {. } \\
\text { Trilobed } \\
\text { Almost straight } \\
\text { Almost round...... } \\
\text { Rosette-shaped.... } \\
\text { Not united..... } \\
\text { Pyriform } \\
28-32 \mu \text { by } 15-18 \mu\end{array}$ & $\begin{array}{l}\text { Linguiform } \\
3 \text { to } 3.5 \mathrm{~mm} \\
1 \mathrm{~mm} . \\
155 \text { to } 262 \mu \text { by } 232 \text { to } \\
278 \mu \text {. } \\
150 \mu \text { by } 200 \mu \\
170 \text { to } 186 \mu \text { by } 140 \mu \\
\text { Trilobed. } \\
\text { Sinuous. } \\
\text { Lobed } \\
\text { Compact transverse } \\
\text { coils. } \\
\text { Not united } \\
\text { Slightly twisted........ } \\
30 \mu \text { by } 15 \mu\end{array}$ & $\begin{array}{l}\text { Linguiform. } \\
1.7 \text { to } 2 \mathrm{~mm} \text {. } \\
590 \text { to } 687 \mu \text {. } \\
93 \text { to } 108 \mu \text { by } 140 \\
155 \mu \text {. } \\
125 \mu \text { by } 140 \mu \text {. } \\
108 \text { to } 140 \mu \text { by } 62 \text { to } \\
93 \mu \text {. } \\
\text { Trilobed. } \\
\text { Slightly sinuous. } \\
\text { Oval or slightly } \\
\text { lobed. } \\
\text { Compact trans } \\
\text { verse coils. } \\
\text { Not united. } \\
\text { Pyriform. } \\
22 \mu \text { by } 11 \mu .\end{array}$ \\
\hline
\end{tabular}




\section{REFERENCES}

Hung, See-Lü.

1926. A new species of fluke, Parametorchis noveboracensis, from the cat in the United States, Proc. U. S. Nat. Mus., Wash. (2627), vol. 69 , art. 1 , pp. $1-2$, fig. 1 .

SkRJABIN, K. I.

1913. Vogeltrematoden aus Russich Turkestan, Zool. Jahrb., Jena., Abt. f. Syst., vol. 35, pp. 351-388, pls. 13-14, figs. 1-16.

Stiles, Ch. Wardell; and Hassall, albert.

1894. A new species of fluke (Distoma [Dicrocoelium] complexum) found in cats in the United States, with bibliographies and diagnoses of allied forms. (Notes on parasites, 21.) Vet. Mag., Phila., vol. 1, June, pp. 413-432, pls. 1-4, figs. 1-19. [MS. dated March 2, 1893.] 



\title{
THE BRYOZOAN FAUNA OF THE GALAPAGOS ISLANDS
}

\author{
By Ferdinand Canu \\ of Versailles, France \\ AND \\ R. S. BASSLER \\ of Washington, District of Columbia
}

\section{INTRODUCTION}

Continuing our investigations of the dredgings of the United States Fish Commission steamer Albatross preserved in the United States National Museum, we have recently completed the study of the material collected from a few stations in the vicinity of the Galapagos Islands. As a result we find that the bryozoa of the Galapagos afford equally interesting results as other classes of animals from this classic area. In the pursuit of these studies we have had financial assistance from the American Association for the Advancement of Science, which help is here gratefully acknowledged.

Located on the equatorial line, the bryozoan fauna of the Galapagos Islands is found to be particularly interesting to the paleontologist. The species common with the Gulf of Mexico indicate the ancient communication of the Pacific with the Atlantic and the very recent formation of the Isthmus of Panama. These species are Acanthodesia savartii, Aplousina filum, Callopora tenuirostris, Callopora curvirostris, Cupuladria umbellata, Puellina innominata, Trypostega venusta, Hippoporina cleidostoma, Mamillopora cupula, and Lichenopora radiata. None of these is known to have made the circuit of any of the continents, so that free communication between the two oceans must have existed.

Another remarkable phenomenon is the persistence in this region of archaic forms known hitherto only as fossils and in which naturally the anatomic structure was unknown. Very useful comparisons can thus be made by means of such species as Proboscina lamellifera, Plagioecia subpapyracea, Diaperoecia (Reticulipora) mean-

No. 2810.-Proceedings U. S. National Museum, Vol. 76, Art. 13. $61589-29-1$ 


\section{$2 \mathrm{BHL}$ Biodiversity Heritage Library}

Aldrich, John Merton. 1929. "Revision of the two-winged flies of the genus Coelopa Meigen in North America." Proceedings of the United States National Museum 76(2808), 1-13. https://doi.org/10.5479/si.00963801.76-2808.1.

View This Item Online: https://www.biodiversitylibrary.org/item/88912

DOI: https://doi.org/10.5479/si.00963801.76-2808.1

Permalink: https://www.biodiversitylibrary.org/partpdf/65583

\section{Holding Institution}

Smithsonian Libraries

\section{Sponsored by}

Smithsonian

\section{Copyright \& Reuse}

Copyright Status: Public domain. The BHL considers that this work is no longer under copyright protection.

This document was created from content at the Biodiversity Heritage Library, the world's largest open access digital library for biodiversity literature and archives. Visit BHL at https://www.biodiversitylibrary.org. 